\title{
Image analysis derived ploidy and proliferation indices in soft tissue sarcomas: Comparison with clinical outcome
}

\author{
B A Michie, C Black, R P Reid, A Barrett, D L Hamblen
}

\begin{abstract}
Aims-To compare prognostic information obtained by image analysis cytometry of paraffin wax embedded soft tissue sarcomas with conventional assessment. Methods-A CAS 200 image analyser was used to determine DNA content of Feulgen stained cytology preparations and tissue sections and to quantify immunostaining by Ki67 and PC10 antibodies. A mitotic count in $\mathbf{5 0}$ high power fields was undertaken and histological grade assigned by the Trojani system. Clinical details including follow up and outcome were obtained by case note review. The Kruskal-Wallis one way analysis test, Spearman $\rho$ significance test, Kaplan-Meier method, and log-rank test were applied in statistical analysis.

Results-Ploidy status, DNA index, 2.5c exceeding rate, $5 \mathrm{c}$ exceeding rate, mitotic count and Trojani grade all correlated significantly with clinical outcome. The relation between Ki67 index and outcome did not reach significance. The PC10 index and outcome were not related. Only $2 \cdot 5 c$ exceeding rate, 5c exceeding rate, and mitotic count correlated significantly with Trojani grade.
\end{abstract}

Conclusions-DNA content determination of soft tissue sarcomas by image analysis provides quantifiable information of benefit in prediction of outcome. Larger series are required to determine the independent value of ploidy. In this study quantification of anti-Ki67 and anti-PC10 immunostaining was not of prognostic benefit) by contrast with mitotic count and Trojani grade.

(F Clin Pathol 1994;47:443-447)

Soft tissue sarcomas are often associated with poor patient survival. Conventional assessment of prognosis includes evaluation of histological type, grade, anatomical site, and stage. Histological type alone is not usually a prognostic indicator whereas grade is more predictive. ${ }^{1}$ The most reproducible soft tissue sarcoma grading system to date is the Trojani system, a scoring system that assesses degree of differentiation, extent of necrosis, and mitotic activity. ${ }^{1}$ Although of recognised value as an indicator of prognosis there are numerous instances where Trojani grade and outcome are not in concordance. ${ }^{2}$ The work of Enneking $^{3}$ has led to improved clinicopatho- logical staging of soft tissue tumours although some of the staging criteria are difficult to apply.

There is thus a need to identify additional prognostic indicators in this discipline. Image analysis cytometry offers a means of measuring DNA content (ploidy) while preserving tissue architecture and cytological detail. Ploidy determination by image analysis is a significant prognostic indicator in many malignancies. ${ }^{4-8}$ Similarly, immunostaining of cell cycle related antigens, for example $\mathrm{Ki} 67$ and PC10, has been widely used to predict survival..$^{10}$ Microwave retrieval ${ }^{11}$ allows application of Ki67 antibody to retrospective paraffin embedded material. This study was undertaken to determine if ploidy and proliferation data obtained by image analysis of paraffin wax embedded soft tissue sarcomas correlate with patient survival and to compare these data with conventional assessment of Trojani grade and mitotic count.

\section{Methods}

Thirty three soft tissue sarcomas were selected from the files of the Scottish Bone Tumour Registry and the Pathology Department. The sample was chosen to examine a range of histological types and a range of grades. Case note review was undertaken and histological diagnosis, site, follow up, treatment, and survival was extracted. All haematoxylin and eosin stained slides for each case were reviewed and one tissue block was selected from the most poorly differentiated area. Only prechemotherapy or preradiotherapy blocks were used. Sections $(3 \mu \mathrm{m})$ for proliferation analysis by immunostaining were mounted on poly-1-lysine coated slides, $3,5,7,9,11$, and $15 \mu \mathrm{m}$ sections for ploidy analysis were mounted on conventional slides and a $50 \mu \mathrm{m}$ section for disaggregation placed in a glass universal container. All sections were dewaxed in xylene and hydrated in graded alcohols.

The $50 \mu \mathrm{m}$ sections were disaggregated by a modification of the standard method of Hedley et al..$^{12}$ The sections were incubated for 120 minutes at $37^{\circ} \mathrm{C}$ in $2 \mathrm{ml}$ of $0.9 \%$ pepsin in normal buffered saline adjusted to pH 1.5 with $2 \mathrm{~N} \mathrm{HCl}$. The resulting suspension was centrifuged for three minutes and the pellet resuspended in buffered saline and cytocentrifuged on to glass slides in a Shadow Cytospin 2 at $650 \mathrm{rpm}$ for five minutes.

The cytospin and histology sections for ploidy analysis were hydrolysed in $5 \mathrm{~N} \mathrm{HCl}$ for 
60 minutes and transferred to Feulgen stain solution (Becton-Dickinson, Oxford, UK) for 60 minutes. After three rinses in rinse reagent (Becton-Dickinson, Oxford, UK) the slides were washed in deionised water, immersed in acid alcohol for five minutes, dehydrated, cleared in xylene, and coverslips were added. A control slide imprinted with rat hepatocytes of known DNA content was added to each batch to calibrate the image analyser and ensure adequate staining.

The $3 \mu \mathrm{m}$ cytospin slide section and the thickest section from the remainder (5-15 $\mu \mathrm{m}$ ) from which sufficient nuclei could be counted were analysed for each case with a CAS 200 Image Analyser (BectonDickinson, Oxford, UK). A minimum of 300 tumour cells and 50 diploid control cells (lymphocytes, polymorphs, or connective tissue cells) were analysed and the data presented as a DNA histogram. In tissue sections control and tumour cell spindle shaped nuclei were only measured in the longitudinal plane.

Ploidy was assigned by combined interpretation of cytospin and tissue section histograms. An average DNA index of the main histogram peak for each case was calculated. A DNA index of $0.9-1 \cdot 1$ was accepted as diploid, $<0.9$ or $1.11-1.30$ as near diploid aneuploid, and $>1.3$ as aneuploid. The $2.5 \mathrm{c}$ exceeding rate and $5 c$ exceeding rate are the proportions of tumour nuclei with a DNA content of more than 2.5 and 5 times haploid respectively. Average $2 \cdot 5 \mathrm{c}$ and $5 \mathrm{c}$ exceeding rates were calculated for each case and expressed as a percentage.

Tissue sections for Ki67 immunostaining were microwaved twice for five minutes in preboiled $10 \mathrm{mM}$ citrate buffer adjusted to pH 6.0 with $2 \mathrm{~N}$ sodium hydroxide. Primary Ki67 monoclonal antibody (Dakopatts, High Wycombe, UK) was applied at 1:25 dilution, incubated for 120 minutes at room temperature, and binding detected by the avidinbiotin method. Primary PC10 monoclonal antibody was applied at a one in 200 dilution and incubated for 16 hours at $4^{\circ} \mathrm{C}$ and immunostaining was detected by the same method. All immunostained sections were counterstained with methyl green. Small intestine, lymph node, proliferative endometrium, myometrium and skin sections were included in each immunostaining batch as controls and a negative control (same protocol without primary antibody) was included for each case.

Immunostaining was quantified by measuring a minimum of 20 random fields or 1000 nuclei with CAS 200 Quantitative Proliferation Index software. Mitotic figures in 50 high power fields ( $\times 400$ magnification, field area $=0.2 \mathrm{~mm}^{2}$ ) were counted. Trojani grade was assigned using all pretreatment haematoxylin and eosin sections in view of the need to assess the extent of necrosis

The significance of any correlation between the continuous variables (DNA index, $2 \cdot 5 \mathrm{c}$ exceeding rate, $5 c$ exceeding rate, $\mathrm{Ki} 67$ index, PC10 index, and mitotic count) and Trojani grade was calculated with the Kruskal-Wallis one way analysis test, and the relation between ploidy assignation and grade by the Spearman $\rho$ test. The $2 \cdot 5 \mathrm{c}$ exceeding rate, 5c exceeding rate, mitotic count, Ki67 index, and PC10 index were each separated into high and low groups by the median. Survival curves were used as the measure of clinical

Ploidy and proliferation indices in soft tissue sarcomas

\begin{tabular}{|c|c|c|c|c|c|c|c|c|c|c|c|}
\hline \multicolumn{2}{|c|}{ Classification Diagnosis } & $\begin{array}{c}\begin{array}{c}\text { Follow up } \\
\text { (months) }\end{array} \\
60\end{array}$ & $\begin{array}{l}\begin{array}{l}\text { Trojani } \\
\text { grade }\end{array} \\
\text { II }\end{array}$ & $\begin{array}{l}\begin{array}{l}\text { Clinical } \\
\text { status }\end{array} \\
\mathrm{DOD}\end{array}$ & $\begin{array}{l}\text { Ploidy } \\
\text { A }\end{array}$ & $\begin{array}{l}\begin{array}{l}D N A \\
\text { index }\end{array} \\
1.35\end{array}$ & $\begin{array}{l}2 \cdot 5 c \\
(\%) \\
50.4\end{array}$ & $\begin{array}{l}\begin{array}{l}5 c \\
(\%)\end{array} \\
4 \cdot 1\end{array}$ & \begin{tabular}{|c|}
$\begin{array}{l}\text { Mitotic } \\
\text { count }\end{array}$ \\
30
\end{tabular} & $\begin{array}{c}\begin{array}{l}\text { Ki67 } \\
\text { index }\end{array} \\
0 \cdot 78\end{array}$ & $\begin{array}{l}\begin{array}{l}P C 10 \\
\text { index }\end{array} \\
24.4\end{array}$ \\
\hline $\begin{array}{r}1 \\
2 \\
3 \\
4 \\
5 \\
6 \\
7 \\
8 \\
9 \\
10 \\
11 \\
12 \\
13 \\
14 \\
15 \\
16 \\
17 \\
18 \\
19 \\
20 \\
21 \\
22 \\
23 \\
24 \\
25 \\
26 \\
27 \\
28 \\
29 \\
30 \\
31 \\
32 \\
33\end{array}$ & $\begin{array}{l}\text { Fibrosarcoma } \\
\text { Myxoid fibrosarcoma } \\
\text { Malignant fibrous histiocytoma } \\
\text { Myxoid liposarcoma } \\
\text { Myxoid liposarcoma } \\
\text { Myxoid liposarcoma } \\
\text { Myxoid liposarcoma } \\
\text { Round cell liposarcoma } \\
\text { Round cell liposarcoma } \\
\text { Leiomyosarcoma } \\
\text { Leiomyosarcoma } \\
\text { Alveolar rhabdomyosarcoma } \\
\text { Haemangiopericytoma } \\
\text { Haemangiopericytoma } \\
\text { Synovial sarcoma } \\
\text { Synovial sarcoma } \\
\text { Synovial sarcoma } \\
\text { Malignant schwannoma } \\
\text { Malignant schwannoma } \\
\text { Malignant schwannoma } \\
\text { Malignant mesenchymoma } \\
\text { Epithelioid sarcoma } \\
\text { Epithelioid sarcoma } \\
\text { Epithelioid sarcoma } \\
\text { Epithelioid sarcoma } \\
\text { Epithelioid sarcoma } \\
\text { Soft tissue sarcoma } \\
\text { Soft tissue sarcoma } \\
\text { Soft tissue sarcoma } \\
\text { Soft tissue sarcoma } \\
\text { Soft tissue sarcoma } \\
\text { Soft tissue sarcoma } \\
\text { Alveolar soft part sarcoma }\end{array}$ & $\begin{array}{r}60 \\
36 \\
21 \\
131 \\
120 \\
50 \\
31 \\
12 \\
6 \\
13 \\
14 \\
48 \\
38 \\
33 \\
60 \\
98 \\
12 \\
44 \\
17 \\
55 \\
36 \\
75 \\
133 \\
72 \\
131 \\
14 \\
21 \\
48 \\
24 \\
6 \\
27 \\
6 \\
121\end{array}$ & $\begin{array}{l}\text { II } \\
\text { I } \\
\text { II } \\
\text { I } \\
\text { II } \\
\text { II } \\
\text { I } \\
\text { I } \\
\text { II } \\
\text { III } \\
\text { II } \\
\text { III } \\
\text { I } \\
\text { I } \\
\text { II } \\
\text { I } \\
\text { I } \\
\text { III } \\
\text { II } \\
\text { I } \\
\text { II } \\
\text { II } \\
\text { II } \\
\text { II } \\
\text { II } \\
\text { I } \\
\text { III } \\
\text { II } \\
\text { III } \\
\text { I } \\
\text { III } \\
\text { III } \\
\text { I }\end{array}$ & $\begin{array}{l}\text { DOD } \\
\text { NED } \\
\text { EOD } \\
\text { NED } \\
\text { MD } \\
\text { DOD } \\
\text { DOD } \\
\text { DOD } \\
\text { MD } \\
\text { MD } \\
\text { NED } \\
\text { DOD } \\
\text { EOD } \\
\text { NED } \\
\text { EOD } \\
\text { NED } \\
\text { EOD } \\
\text { NED } \\
\text { DOD } \\
\text { EOD } \\
\text { DOD } \\
\text { MD } \\
\text { NED } \\
\text { NED } \\
\text { NED } \\
\text { MD } \\
\text { DOD } \\
\text { NED } \\
\text { DOD } \\
\text { NED } \\
\text { DOD } \\
\text { NED } \\
\text { NED }\end{array}$ & $\begin{array}{l}\text { A } \\
\text { A } \\
\text { A } \\
\text { D } \\
\text { NDA } \\
\text { A } \\
\text { NDA } \\
\text { NDA } \\
\text { NDA } \\
\text { A } \\
\text { A } \\
\text { A } \\
\text { D } \\
\text { D } \\
\text { NDA } \\
\text { NDA } \\
\text { D } \\
\text { NDA } \\
\text { A } \\
\text { D } \\
\text { A } \\
\text { NDA } \\
\text { NDA } \\
\text { D } \\
\text { NDA } \\
\text { A } \\
\text { A } \\
\text { D } \\
\text { D } \\
\text { NDA } \\
\text { A } \\
\text { NDA } \\
\text { NDA }\end{array}$ & $\begin{array}{l}1.35 \\
1.50 \\
2.26 \\
1.04 \\
1.28 \\
2.41 \\
1 \cdot 15 \\
1 \cdot 10 \\
1 \cdot 22 \\
2 \cdot 74 \\
1 \cdot 72 \\
1.41 \\
1.08 \\
1.04 \\
1 \cdot 13 \\
0.82 \\
0.99 \\
1.17 \\
2.75 \\
0.96 \\
3.13 \\
0.96 \\
1.11 \\
1.09 \\
1.13 \\
1.72 \\
1.63 \\
0.98 \\
0.93 \\
1.24 \\
2.86 \\
1.28 \\
1.19\end{array}$ & $\begin{array}{c}50 \cdot 4 \\
74 \cdot 5 \\
41 \cdot 3 \\
14 \cdot 3 \\
50 \cdot 1 \\
50 \\
4 \cdot 35 \\
4 \cdot 3 \\
27 \cdot 2 \\
68 \cdot 3 \\
52 \cdot 2 \\
86 \\
21 \cdot 8 \\
22 \cdot 4 \\
21 \\
7 \\
10 \cdot 4 \\
32 \cdot 8 \\
88 \cdot 7 \\
8 \cdot 7 \\
99 \\
4 \cdot 9 \\
37 \cdot 7 \\
27 \cdot 2 \\
70 \cdot 6 \\
63 \cdot 8 \\
73 \\
8 \cdot 7 \\
41 \\
41 \cdot 6 \\
61 \cdot 7 \\
49 \cdot 3 \\
37\end{array}$ & 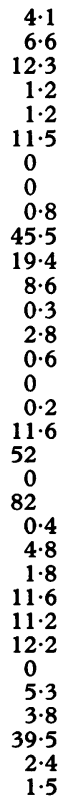 & $\begin{array}{r}30 \\
0 \\
3 \\
2 \\
1 \\
0 \\
0 \\
0 \\
0 \\
30 \\
11 \\
89 \\
9 \\
15 \\
36 \\
5 \\
12 \\
128 \\
0 \\
6 \\
85 \\
4 \\
6 \\
8 \\
3 \\
7 \\
126 \\
5 \\
81 \\
1 \\
195 \\
8 \\
0\end{array}$ & $\begin{array}{l}0 \cdot 78 \\
3 \cdot 23 \\
1 \cdot 38 \\
2 \cdot 55 \\
0 \\
1 \cdot 28 \\
6 \cdot 24 \\
1 \cdot 29 \\
1 \cdot 32 \\
0 \cdot 78 \\
8 \cdot 96 \\
2 \cdot 07 \\
3 \cdot 37 \\
0 \cdot 93 \\
0 \\
1 \cdot 17 \\
2 \cdot 83 \\
0 \\
0 \cdot 5 \\
0 \\
1 \cdot 34 \\
1 \cdot 78 \\
0 \\
0 \\
0 \\
0 \\
0 \cdot 31 \\
0 \\
0 \cdot 93 \\
0 \\
2 \cdot 46 \\
0 \\
0.91\end{array}$ & 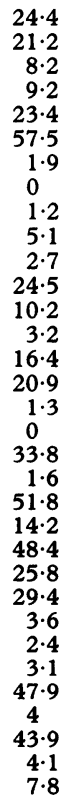 \\
\hline
\end{tabular}

$\mathrm{NED}=$ no evidence of disease; $\mathrm{EOD}=$ evidence of disease; $\mathrm{MD}=$ metastatic disease; $\mathrm{DOD}=$ died of disease; $\mathrm{D}=$ diploid; $\mathrm{NDA}=$ near diploid aneuploid $A=$ aneuploid. 
Figure 1 Relation between DNA index and survival.

Figure 2 Relation between Ki67 index and survival.

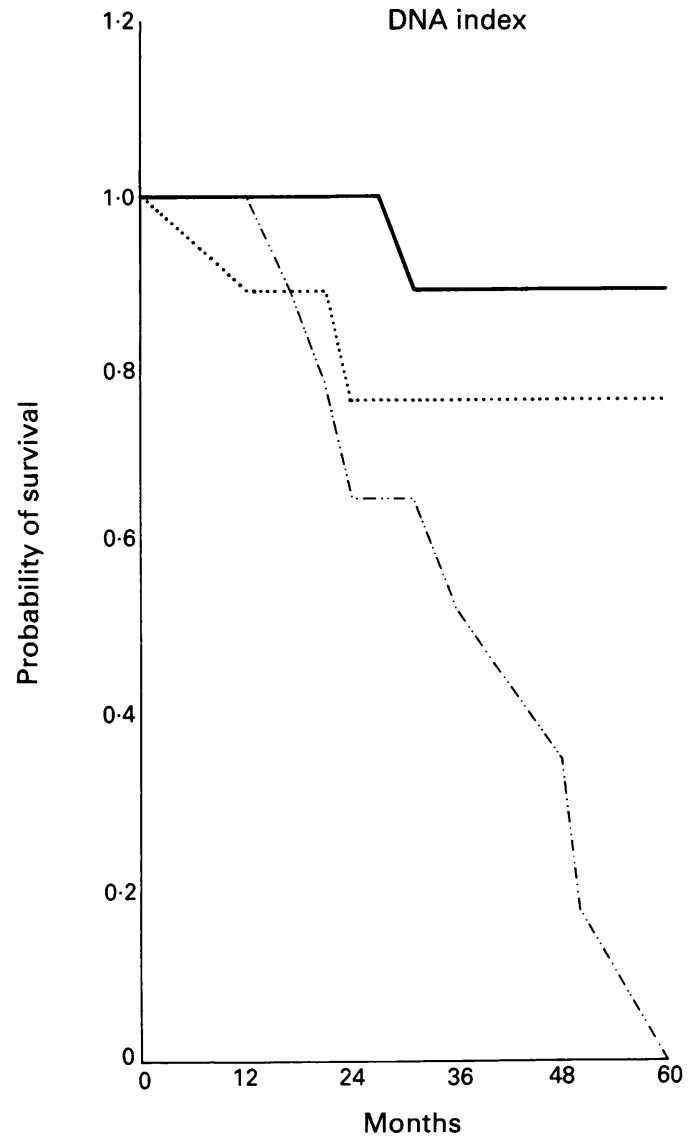

outcome and plotted by the Kaplan-Meier method and significance was calculated by the log-rank test.

\section{Results}

The table presents the data. When compared with outcome, aneuploidy ( $p=0.007)$, high DNA index $(>1 \cdot 3, \mathrm{p}=0.05$; fig 1$)$, high $2.5 \mathrm{c}$ exceeding rate $(>37.7 \%, p=0.0035)$, and high $5 c$ exceeding rate $(>3.8 \%, p=0.003)$ were each associated with significantly diminished survival. Similarly high mitotic count $(>10 / 50$ at high power fields, $p=0.035)$ and Trojani grade III ( $p=0.021)$ were associated with poor survival. There was a trend when Ki67 index was plotted against outcome (fig 2) but significance was not attained $(\mathrm{p}=0 \cdot 88)$.

Mitotic count ( $p=0.001$, fig 3$), 2 \cdot 5 c$ exceeding rate $(p=0.03)$, and $5 c$ exceeding rate $(p=0.003)$ correlated significantly with Trojani grade whereas ploidy assignation $(\mathrm{p}=$ $0 \cdot 131)$, DNA index $(p=0 \cdot 159), \mathrm{Ki} 67$ index $(p=0.574)$, and PC10 index $(p=0.108)$ did not.

PLOIDY ANALYSIS

Adequate Feulgen staining of calibration slides was achieved in each batch. Insufficient control nuclei were identified in one cytospin
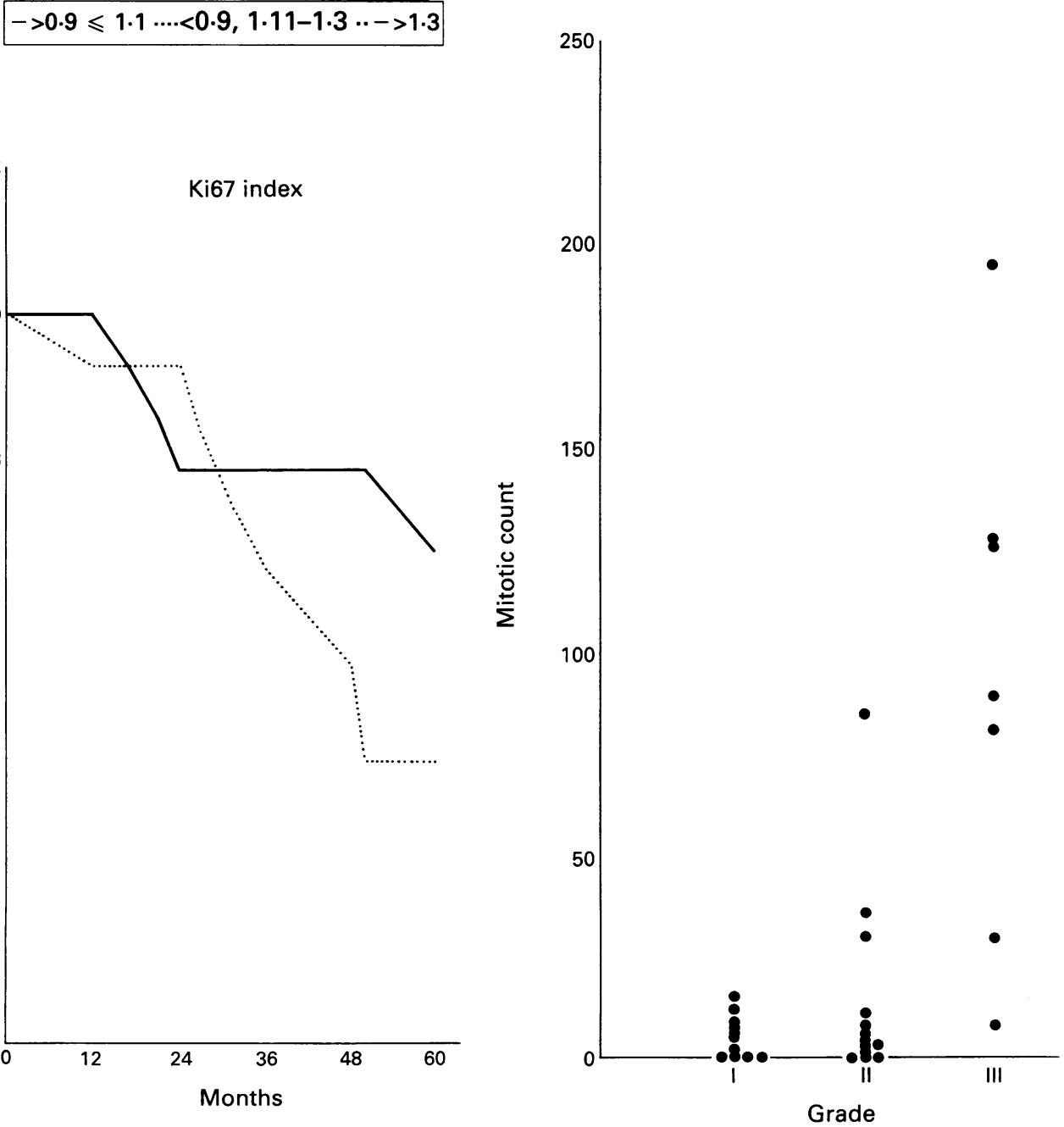

Figure 3 Relation between Trojani grade and mitotic count. 
preparation where the average human cellular DNA content of $7 \cdot 18 \mathrm{pg}$ was used to position diploidy in relation to the histogram. In the remaining cytospins lymphocyte nuclei were used as controls in 25 cases and polymorphonuclear granulocytes in seven. No tissue section histograms were generated in six cases due to excess nuclear overlap. In these cases the cytospin alone was utilised. Only the $3 \mu$ tissue section was suitable for ploidy analysis in a further six cases. Benign non-endothelial spindle cells were used as controls in most $(65 \%)$ tissue sections and lymphocytes were used as control cells in the remainder.

Average coefficient of variation of the main peak ranged from $2.41 \%$ to $28.4 \%$ (mean $9 \cdot 3 \%$ ). This value was diminished in cytospins (mean 6.9\%) indicating generally narrower peaks. In one case a diploid histogram was obtained by cytospin analysis of presumed tumour cells whereas tissue section histograms were of a clearly aneuploid tumour. A total of three hypodiploid near diploid aneuploid (DNA index <0.9) histograms were generated.

\section{PROLIFERATION ANALYSIS}

Both anti-Ki67 and anti-PC10 immunostaining were confined to nuclei, and control tissues revealed staining patterns expected for proliferation markers: the proliferative compartments of endometrium, intestinal crypts, and lymph nodes were positively stained whereas myometrium and gastrointestinal stromal cells were negative. Negative controls were not immunostained. In general antiKi67 and anti-PC10 immunostaining was uniform. There was no anti-Ki67 immunostaining in 11 cases and anti-PC10 was negative in two. Indices obtained for PC10 (mean $16.7 \%$ ) were generally higher than those for Ki67 (mean 1.58\%). There was no statistical correlation between the proliferation indices (Ki67 index, PC10 index, and mitotic count).

\section{Discussion}

Ploidy status and related indices (DNA index, $2 \cdot 5 c$ exceeding rate, and $5 c$ exceeding rate) correlated significantly with survival. These results indicate that image analysis ploidy assessment is a useful prognostic indicator in soft tissue sarcomas. The value of $2 \cdot 5 c$ and $5 c$ exceeding rates has been recognised before. ${ }^{13}$ Interestingly, these indices also correlated with Trojani grade whereas ploidy assignation and DNA index did not. There are conflicting results with regard to the relation between ploidy and Trojani grade in previous studies. ${ }^{14} 15$ It is our opinion that it is more important that a potential indicator of prognosis correlate with survival rather than grade. Larger series are required to assess independently the value of ploidy in this discipline by multivariate analysis and to assess ploidy of individual histological types of soft tissue sarcoma.

The acceptable range of diploid by image analysis is debatable. Some authors accept up to a DNA index of 1.25 as diploid whereas others recognise near diploid aneuploidy. ${ }^{6}$
Hypodiploid histograms were generated in three instances in the current study. The possibility that tumour cells can lose DNA (hypodiploidy) during replication-for example, by deletions-leads to theoretical misgivings regarding flow cytometry where the first histogram peak is usually regarded as diploid without any means of excluding hypodiploidy.

In some previous studies 100-200 tumour cell nuclei were measured. ${ }^{131416}$ Recently it has been recognised that for statistical purposes measurement of 300 nuclei is more accurate. ${ }^{17}$ Hence 300 tumour cells and 50 control cells were measured in each sample in this study. In most previous series lymphocytes have been used to position diploidy and lymphocytes are recognised as adequate control cells in cytology preparations. ${ }^{13}$ In tissue sections the small nuclear area of a lymphocyte can lead to setting of an incorrect low diploid DNA content value. Similarly, the spiral configuration of endothelial cells in tissue sections can lead to under-representation of tissue section diploidy. ${ }^{16}$ Both lymphocytes and endothelial cells were avoided as controls in tissue sections in this study.

Preservation of tissue architecture and ease of preparation are the advantages of ploidy assessment from tissue sections. There are, however, theoretical drawbacks in that the number of incomplete partially sectioned nuclei increases with decreasing section thickness. There was broad agreement between cytology preparation data and tissue section data in this study and in one case tissue section analysis was critical to accurate ploidy assignment. No polidy data were obtained on tissue sections due to excess nuclear overlap in $18 \%$ of the cases. We believe that tissue section ploidy analysis should only be used in combination with cytology preparation analysis, which is recognised as the "gold standard" because most nuclei are intact.

The proliferation analysis results are less conclusive. There was a recognisable trend between high $\mathrm{Ki} 67$ index and poor outcome but significance was not attained. The protocol for application of Ki67 antibody to paraffin embedded material has only recently become available $^{11}$ and presumably the value of this antibody as a prognostic indicator will soon be elucidated. There are theoretical misgivings about the suitability of PC10 antibody as a proliferation marker and prognostic indicator due to the role of the antigen in DNA repair, its long half life, its expression in non-cycling cells, and its inducibility by growth factors. ${ }^{10}$ The PC10 index was of no value in this study.

Mitotic count is often used as a routine prognostic indicator, is of recognised value in soft tissue sarcomas, and is incorporated in the Trojani grading system. It is not surprising that mitotic count and Trojani grade correlated significantly with each other and with survival.

In conclusion, assessment of ploidy by image analysis is of value in the prediction of likely outcome in a patient with a soft tissue sarcoma established by biopsy. Similarly, conventional assessment of Trojani grade and 
mitotic count is also of proved utility. Ki67 index requires further evaluation in this field, whereas PC10 index is unlikely to be useful.

1 Trojani M, Contesso G, Coindre JM, Rouesse J, Bui NB, Mascarel A, Goussot JF, David M, Bonichon F, Lagarde C. Soft tissue sarcomas of adults; study of pathological prognostic variables and definition of a histopathological grading system. Int $f$ Cancer 1984;33:37-42.

2 Donohue JH, Collin C, Friedrich C, Godbold J, Hajdu SI, Brennan MF. Low grade soft tissue sarcomas of the Brennan MF. Low grade soft tissue sarcomas of the extremities. Analysis

3 Enneking WF. A system of staging musculo-skeletal neoplasms. Clin Orthop 1986;204:9-24.

4 Hall TL, Fu YS. Applications of quantitative microscopy in tumour pathology. Lab Invest 1985;53:5-21.

5 Miller BE, Lavia LA, Horbelt DV. The prognostic significance of image analysis in ovarian cancer. Cancer 1991; 67:1318-21.

6 Auer G, Askensten U, Ahrens O. Cytophotometry. Hum Pathol 1989;20:518-27.

7 Fallenius AG, Franzen SA, Auer GU. Predictive value of nuclear DNA content in breast cancer in relation to clinical and morphological factors. A retrospective study of ical and morphological factors. A retrospective

8 Merkel DE, MacGuire WL. Ploidy, proliferative activity and prognosis. DNA flow cytometry of solid tumours. Cancer 1990;65:1194-205.
9 Brown DC, Gatter KC. Monoclonal antibody Ki67: its use in histopathology. Histopathology 1990;17:489-503. 10 McCormick D, Hall PA. The complexities of proliferating McCormick D, Hall PA. The complexities of prolifer
cell nuclear antigen. Histopathology 1992;21:591-4.

11 Gerdes J, Becker MHG, Key G, Cattoretti G. Immunohistological detection of tumour growth fraction (Ki67 antigen) in formalin fixed and routinely processed tissues. F Pathol 1992;168:85-6.

12 Hedley DW, Friedlander ML, Taylor IW, Rugg C, Musgrove A. Method of analysis of cellular DNA content of paraffin-embedded pathological material using flow cytometry. $\mathcal{F}$ Histochem Cytochem 1983;31:1333-5.

13 Dorman A, Graham D, Curran B, Hendry K, Leader M Ploidy of smooth muscle tumours: retrospective image analysis study of formalin fixed, paraffin wax embedded analysis study of formalin fixed, paraff
tissue. $¥$ Clin Pathol 1990;43:465-8.

14 Herzberg AJ, Kerns BJ, Honkanen FA, Pence JC, Iglehart $J D$, Kinney RB. DNA ploidy and proliferation index of soft tissue sarcomas determined by image cytometry of fresh frozen tissue. Am $\mathcal{F}$ Clin Pathol 1992;97(suppl 1): S29-S37.

15 Kroese MCS, Rutgers DH, Wils IS, Van Unnik JA, Roholl PJ. The relevance of DNA index and proliferation rate in the grading of benign and malignant soft tissue tumours. Cancer 1990;65:1782-8.

16 Lanigan D, McLean PA, Curran B, Leader M Comparision of flow and static image cytometry in the determination of ploidy. $¥$ Clin Pathol 1993;46:135-9.

17 Wied GL, Bartels PH, Bibbo M, Dytch HE. Image analysis in quantitative cytopathology and histopathology. Hum Pathol 1989;20:549-71. 